\title{
ANDROGENIC REGULATION OF PLASMA PROSTAGLANDIN F LEVELS IN THE RAT
}

\author{
B. BARCIKOWSKI, S. K. SAKSENA AND A. BARTKE* \\ Worcester Foundation for Experimental Biology, Shrewsbury, \\ Massachusetts 01545 , U.S.A.
}

(Received 19th Fune 1973)

Prostaglandins (PGs) can be synthesized by the testes (Ellis, 1972) and are present in the male accessory reproductive tissues and in the semen of various mammalian species (Bygdeman, Fredricsson, Svanborg \& Samuelsson, 1970; Tan \& Privett, 1972). Their physiological rôle in the male reproductive system is not understood but various effects of PG administration on the testes and male reproductive tract have been reported. These include decrease in plasma testosterone levels (Bartke, Musto, Caldwell \& Behrman, 1973; Saksena, Safoury \& Bartke, 1973), decrease in testicular blood flow (Free \& Jaffe, 1972), and effects on contractions of the testis capsule (Seeley, Hargrove, Johnson \& Ellis, 1972), on sperm transport (Hunt \& Nicholson, 1972), and on contractile responses of the ductus deferens and seminal vesicles in vitro (Stahl, 1972; Taylor \& Einhorn, 1972). In the human, certain cases of male infertility appear to be associated with a low seminal content of PGs (Bygdeman et al., 1970) and an increase in seminal PGs was recorded after administration of HCG or an androgen, $1 \alpha$-methyl- $5 \alpha$-androstan-17 $\beta$-ol-3-one, mesterolon (Sturde, 1971; Sturde \& Bohm, 1971). This latter work suggests that the production of seminal PGs in the human is under androgenic control. In view of these observations, we have examined the effects of castration and androgen replacement therapy on PGF levels in the peripheral plasma of male rats.

Adult Charles River CD rats of proven fertility were allocated to the following groups: (1) intact controls; (2) castrated and killed after 1 week; (3) castrated and killed after 2 weeks; (4) castrated and, beginning 1 week later, treated daily for 7 days with $100 \mu \mathrm{g}$ testosterone propionate (TP) subcutaneously in $0.2 \mathrm{ml}$ sesame oil; (5) castrated and treated with $250 \mu \mathrm{g}$ TP on the same schedule; (6) castrated and treated with sesame oil alone, using the same schedule as for TP administration. Animals in groups (4), (5) and (6) were killed 1 day after the last injection. Blood collected with a $10-\mathrm{ml}$ heparinized syringe from the abdominal aorta of rats under Nembutal anaesthesia was immediately centrifuged (refrigerated model). The levels of PGF in plasma obtained from heparinized refrigerated blood do not show any increase from 0 to 1 hr (I. F. Lau, V. D. Castracane and S. K. Saksena, unpublished observations). In the procedure used, clotting does not take place and consequently prostaglandin formation by platelets is prevented. The plasma was stored frozen until it was assayed.

\section{* Reprint requests to A. Bartke.}


The levels of PGF in the plasma were determined by radioimmunoassay. In this procedure, approximately $1500 \mathrm{~d} / \mathrm{min}$ of $\left[{ }^{3} \mathrm{H}\right] \mathrm{PGF}_{2 \alpha}$ and $\mathrm{pH} 4.5$ acetate buffer were added to $1 \mathrm{ml}$ plasma and this mixture was extracted with ethyl acetate. After washing with distilled water, the extract was dried and chromatographed on silicic acid columns (Caldwell, Burstein, Brock \& Speroff, 1971). Prostaglandins $\mathrm{F}_{2 \alpha}$ and $\mathrm{F}_{1 \alpha}$ were not distinguishable in the procedure used and consequently the results refer to total PGF concentration (Stylos, Burstein, Rivetz, Gunsalus \& Skarnes, 1972). The water blank values were below 50 pg and assay sensitivity was $100 \mathrm{pg}$. The intra- and inter-assay coefficient of variation was $13.2 \%$ and $18.6 \%$, respectively. The average recovery was $73 \%$. The significance of the differences was calculated by the analysis of variance and Duncan's test.

The levels of PGF in the peripheral plasma of male rats after castration and $\mathrm{TP}$ treatment are given in Table 1 . The concentration appeared to be diminished

Table 1. Concentration of prostaglandin $\mathrm{F}$ in the peripheral plasma of male rats which were intact, castrated, or castrated and treated with testosterone propionate

\begin{tabular}{l|c|c}
\hline \multicolumn{1}{c|}{ Treatment } & No. of rats & $\begin{array}{c}\text { Concentration of } \\
P G F(n g / m l) \dagger\end{array}$ \\
\hline Intact controls & 10 & $2 \cdot 8 \pm 0 \cdot 3$ \\
Castrated (7 days) & 10 & $1 \cdot 8 \pm 0 \cdot 3$ \\
Castrated (14 days) & 7 & $0 \cdot 9 \pm 0 \cdot 1$ \\
Castrated, sesame oil* & 15 & $1 \cdot 2 \pm 0 \cdot 2$ \\
Castrated, 100 $\mu \mathrm{g}$ TP* & 7 & $2 \cdot 0 \pm 0 \cdot 3$ \\
Castrated, 250 $\mu \mathrm{g}$ TP* & 7 & $4 \cdot 1 \pm 1 \cdot 1$ \\
\hline
\end{tabular}

* Administered daily for 7 days beginning 1 week after castration. $\mathrm{TP}=$ testosterone propionate. $\dagger$ Values expressed as mean \pm S.E.

1 week after castration, and after 2 weeks it was significantly reduced. Administration of $250 \mu \mathrm{g}$ TP to the castrated animals caused a significant increase in the plasma PGF levels $(P<0.05)$. The concentration of PGF in the plasma of castrated rats given $100 \mu \mathrm{g}$ or $250 \mu \mathrm{g}$ TP was not significantly different from that observed in intact controls $(P>0.05)$.

The results indicate that androgen levels influence the concentration of PGF in the peripheral plasma of male rats. It appears that either the androgendependent accessory reproductive tissues contribute significantly to the PGF content of peripheral blood, or that production of PGF by non-reproductive tissues is under androgenic control. Preliminary results indicate that treatment of male rats with cyproterone acetate can also change the concentration of PGF in the peripheral plasma. A low dose decreased and a high dose increased PGF levels (S. K. Saksena and B. Barcikowski, unpublished observations). We conclude that plasma PGF levels in adult male rats decrease after castration and can be restored by $\mathrm{TP}$ administration, indicating that androgendependent tissues may serve as an important source of plasma PGs. 
This work was supported by the Ford Foundation through its Training Program in Reproductive Physiology and by NIH Grant 1K04 HD-70369-01. Prostaglandin antiserum was kindly provided by Dr W. A. Stylos.

\section{REFERENCES}

Bartke, A., Musto, N., Caldwell, B. V. \& Behrman, H. R. (1973) Effects of a cholesterol esterase inhibitor and of prostaglandin $F_{2 \alpha}$ on testis cholesterol and on plasma testosterone in mice. Prostaglandins, 3, 97.

Bygdeman, M. B., Fredricsson, B., Svanborg, K. \& Samuelsson, B. (1970) The relation between fertility and prostaglandin content of seminal fluid in man. Fert. Steril. 21, 622.

Caldwell, B. V., Burstein, S., Brock, W. A. \& Speroff, L. (1971) Radioimmunoassay of F-prostaglandins. F. clin. Endocr. Metab. 33, 171.

ElL1s, L. C. (1972) Rat testicular prostaglandin synthesis and its relationship to androgen synthesis. Fedn Proc. Fedn Am. Socs exp. Biol. 31, 295. Abstr.

FREE, M. J. \& JAFFE, R. A. (1972) Effect of prostaglandins on blood flow and pressure in the conscious rat. Prostaglandins, $1,483$.

Hunt, W. L. \& Nicholson, N. (1972) Studies on semen from rabbits injected with $\mathrm{H}^{3}$-thymidine and treated with prostaglandins $\mathrm{E}_{2}$ and $\mathrm{F}_{2 x}$. Fert. Steril. 23, 763.

Saksena, S. K., El Safoury, S. \& Bartke A. (1973) Prostaglandins $E_{2}$ and $F_{2} \alpha$ decrease plasma testosterone levels in male rats. Prostaglandins, 4, 235.

Seeley, R. R., Hargrove, J. L., Johnson, J. M. \& Ellis, L. G. (1972) Modulation of rabbit testicular contractions by prostaglandins, steroids and some pharmacological compounds. Prostaglandins, 2 , 33.

Stahl, P. (1972) Comparative responses of hamster vas deferens and seminal vesicle to the effect of prostaglandins $\mathrm{E}_{1}$ and $\mathrm{E}_{2}$ on stimulation by epinephrine. Prostaglandins, 6, 491.

Sturde, H. G. (1971) Das Verhalten der Sperma-Prostaglandine unter Androgen-Therapie. Arzeneimittel-Forsch. 21, 1293.

Sturde, H. C. \& BoHM, K. (1971) Behaviour of sperm prostaglandins under therapy with gonadotropins. Arzneimittel-Forsch. 21, 986.

Stylos, W. A., Burstein, S., Rivetz, B., Gunsalus, P. \& Skarnes, R. G. (1972) The production of anti F-prostaglandin serum and its use in radioimmunoassay. Intra-Sci. Chem. Rep. 6, 67.

TAN, W. G. \& PRIVETT, O. S. (1972) Analysis of prostaglandins in rat vesicular glands. Lipids, 7, 622.

TAYLOR, G. S. \& EINHORN, V. F. (1972) The effect of prostaglandins on junction potentials in the mouse vas deferens. Eur. F. Pharmacol. 20, 40. 